\title{
ロードプライシングの公平性に関する研究*
}

\section{A Study on the Fairness of Road-Pricing}

柳 時均"*, 山本俊行”**, 北村隆一”*** By Sikyun RYOO, Toshiyuki YAMAMOTO and Ryuichi KITAMURA

\section{1.はじめに}

ロードプライシングは，1960年代からその理論的な 研究がなされてきたが1), 実用化を目指した研究は80年 代に入ってから本格的に行われている．特に，1980年代 の研究が主にロードプライシングの理論的，技術的側面 に焦点を当てた22,3,4)のに対し，1990年代には，主に政治 的な受容の可能性や自動徵収方式の導入可能性を検討す る研究が多くなされてきている5,,6,7),8,9,1,10).

また，ロードプライシングの広域的な導入を視野に 収め, ロードプライシングに対する運転者の対応行動, 予想される問題点を探るための実験プロジェクト，ある いは施行経験に関する報告なども出されつつあり 11),12),13),14), ロードプライシングは，現実的な選択肢となっ てきている.

しかし，ロードプライシングは，社会的な便益の最 大化という効率性尺度から，交通管理者には非常に優れ た混雑緩和策として評価されているが，これを実施する ことに対する市民の反発が非常に強く，実際に施行され ているケースは数少ない15). ロードプライシングが市民 からの強い反発に直面している理由として，適切に料金 収入が再配分されない場合，ほとんどの自動車利用者の 効用水準が低下すること，及び，ロードプライシングが 不公平な政策として認識されていることが挙げられる 1),9),10),166,177.

近年，公平性の観点からロードプライシングを評価 しようとする研究が多くなされてきている99,10),15),18,199. しかし,これらの研究で用いられている公平性の概念は, 主に政策の逆進性と累進性を問うものであり，市民が感 じる不公平感を表すものとは言い難い，例えば，多くの 研究7).8,9,15),20,21)がロードプライシングが及ほす不公平感 の解消方法として, 効用水準の低下した人々の損失分を 料金収入の再配分によって補償する方法を提案している. しかし，不公平感というものが他人との比較によって生 ビるものと考えれば，個人効用の低下分のみを補償する 方法では，人々が感じる不公平感を解消することが不可

\footnotetext{
* キーワード：Road-Pricing, 経路選択, 政策評価

** 学生員京都大学工学研究科土木システム工学 専攻 博士課程

*** 正会員 工修 京都大学工学研究科土木システム工学 専攻 助手

****正会員 Ph.D 京都大学工学研究科土木システム工学 専攻 教授
}

能であると思われる，特に，Lave ${ }^{10)}$ はこのような補償方 法の不適切さを指摘している。

また，公平性の面から交通政策を評価するとき，さ まざまな社会階層(所得水準, 性別, 年齢など)や交通環 境(利用する手段, 経路や公共交通機関の利便性など), 地域特性(出発地と目的地の地理的な位置)を考慮するべ きであるが20)，実際にこのような要因を考虑した上で, 分析的に公平性を検討した研究は未だなされていない。 公平性を定量的に評価できる基準が確立されていない事, 及び，従来の交通量配分においては個人間の異質性が十 分考慮されていない事が，このような研究における1つ の障害になっていると考えられる22).

本研究は，このような背景の下で超公平理論を採用 し，人々の個人属性や交通属性を考虑した上で，ロード プライシングの公平性を定量的に分析する方法を提案す ると共に，個々人の異質性を考慮した上で，仮想的なネ ットワークにおける数值実験を通して次のような疑問に 対する知見を得ることを目指す。

(1)社会的な便益を最大にするロードプライシングは 公平性の観点からも望ましいと評価されうるのか.

(2)どのような形態のロードプライシングが公平性の 側面からより望ましいと評価されるか.

(3)ロードプライシングの不公平性の改善方法として, これまで提案されている料金収入の再配分法は，不 公平性をどの程度是正できるのか.

なお, 本研究では分析対象の範囲を, 対象地域で自 動車を利用する可能性のある潜在的な自動車利用者のみ に限定する。ロードプライシングに反対する人々のほと んどが自動車利用者であると考えれば，このように分析 の対象を限定することによる影響は少ないと考えられる.

以下，2. で本研究で用いる公平性基準について述べ た後，3．にて個々人の効用関数を定義する．4. では 2. で述べた公平性基準と 3. で定義した効用関数を用いて 仮想的なネットワークにおけるロードプライシングの公 平性を検討する，さらに，5．で料金収入を再配分する 事による公平性の改善効果について分析を行い，6. で 本研究で得られた知見をまとめる.

\section{2. 公平性の定量的な測定方法の提案}

\section{1 超公平理論と厚生関数}

政策の公平性を測定する方法は，集計的な方法と非 
集計的な方法に分類することができる22). 集計的な方法 として最も良く用いられるのは厚生関数である. 厚生関 数は, 個々人の効用水準の重み付き和や積, あるいは $\min -\max$ の形として表現されており，最大化すべき目的 関数の形となっている ${ }^{22)}$. よって, 厚生関数を用いて政 策の公平性を評価するためには，個々人の重みを決定す る必要がある．しかしながら，個々人の重みについて客 観的な決定方法は存在せず, 染意的な判断に頼らざるを 得ない.

これに対して，非集計的な方法は主に，公平な政策 として評価されるために满たすべき条件式として表され る. 例えば，“無美望基準”は，政策施行後において， 個々人が自分以外の全ての個人と自分とを比較した時, 全員が自分以外の誰にも羡望(不公平感)を感じない場合 に公平な政策と評価するものである。これに対して，

“平均等価配分' という基準は，平均的な個人を比較 の対象とし, 個々人が比較対象と自分とを比較した時, 誰も美望(不公平感)を感じない場合に公平な政策と評価 するものである.

超公平理論は，無美望条件を政策評価に用いるため に改良したものであり，漸進的な超公平基準は以下のよ うに定義される23).ただし，本稿では線形の効用関数を 仮定するものとする.よって，式(1)の両辺はともに財・ サービスの変化による効用の変化を表す。

$$
u_{i}\left(\Delta x_{i}\right)=\max _{k \in K} u_{i}\left(\Delta x_{k}\right) \quad \forall i \in K
$$

ここで,

$u_{i}$; 個人iの効用関数

$\Delta x_{i}=x_{i}^{a}-x_{i}^{b} ;$ 政策による個人 $i$ の財・サービスの変化べク トル

$x_{i}^{a}, x_{i}^{b} ;$ ロードプライシングの施行前(b)後(a)の個人 $i$ の財 サービスのベクトル

$K$ ：分析対象集団

式(1)は，“政策によって自分自身が最も良くなった” と全ての人々が考えるならば，その政策は公平な政策と 評価されることを示している，本研究では式(1)から次 のような不公平感の集計的な指標 $\mathrm{E}$ を算出し, 政策評 価に用いることを考える.ここで，ある個人について式 (1)の等号が成立しない場合には, 式(2)の右辺第 2 項が 第 1 項より大きくなり, 該当個人の不公平感は两項の差 によって表される.

$$
E=\sum_{i}\left(u_{i}\left(\Delta x_{i}\right)-\max _{k \in K} u_{i}\left(\Delta x_{k}\right)\right) / \beta_{i}
$$

ここで,

\section{$\beta_{i}:$ 金銭に対する個人 $i$ の限界効用率}

パラメータ $\beta_{i}$ は，個々人が感じる不公平感を同一の尺 度(例えば金銭)上で集計するために導入したものである。 バラメータ $\beta_{i}$ を導入する事は, 個々人の重みを恣意的に 判断している事に他ならないが, 全ての個々人において
式(1)が成立するならば,すなわち 1 人も羡望を感じな 认場合，重みに関わらず，不公平感の集計值，指標 $\mathrm{E}$ は最大値 0 になり，超公平理論上で公平な政策と評価さ れることになる。

\section{2 ロードプライシングの公平性の評価方法}

ロードプライシングに対する人々の対応行動は，さ まざまな形として現われると考えられる。例えば，ロー ドプライシングを避けるために目的地を変更したり，利 用する交通機関を変えたり，料金の賦課されない経路を 選択したり，出発時刻をずらすなどの対応行動が考えら れる24).

そしてこのような対応行動の結果として個々人には さまざまな財・サービス(例えば，旅行時間，金錢，自 動車利用など)の量に変化が起こるものと考えることが できる、ここでの財・サービスとは, 個々人の効用水準 に影響を与えるものとして定義されるものであり，個々 人は旅行時間と料金を支払うことによって自動車を利用 するものと考えれば，個々人の選択行動は，以上の $3 つ$ の財・サービスの交換行動として解釈することができる.

本研究では, 分析を単純化するために, トリップの 発生, 目的地及び時間帯は固定されていると仮定する(従 って, 個々人が選択可能な選択肢は経路・交通手段のみ である)。また，ロードブライシングが施行された場合， 潜在的な自動車利用者は次のような 3 つの財・サービス を消費することによって自らの効用水準を最大にするも のと仮定する。

考虑される財・サービス：自動車旅行時間, 料金, 自動車利用

本研究では個々人に与えるロードプライシングの影響を 以上の 3 つの財・サービスにおける変化として捉え, 式 (2)の指標(以下では ‘超公平指標” と呼ぷ)を算出するこ とによりロードプライシングの公平性を定量的に測定す る.

一方，ロードプライシングの公平性に関するこれま での研究で用いられている公平性概念(料金収入の再配 分によって被害者の損失分(効用水準の低下分)を補償す ること と)と式(2)の公平性概念を比較するために, 次のよ うな指標(以下では ‘伝統的な公平性指標” と呼ぷ)を導 入する。

$$
S=\sum_{i \in K} \delta_{i} \bullet u_{i}\left(\Delta x_{i}\right) / \beta_{i}
$$

ここで

$\delta_{i}: u_{i}\left(\Delta x_{i}\right)<0$ 场合には 1, その他には 0

式(3)はロードブライシングによって効用水準が低下 した個々人の効用水準の低下分を金銭に換算して和をと ったものであり, 既存研究での公平性の観点において補 償の対象とされるものである. 従って, ロードプライシ ングによって得られる料金収入が伝統的な公平性指標 
(3)より大きい場合には，集計的な観点からの補償の可 能性を意味するものと考えられる.

\section{3. 効用関数の定義}

ここでは, 前章での仮定に基づいて潜在的な自動車 利用者の効用関数を定義する. まず，トリップの発生， 目的地及び時間帯が固定されているとの仮定により, 個々人の選択肢集合を次のように定義する.

自動車利用(auto):自動車を利用して目的地へ行く. 公共交通機関利用(transit):公共交通機関を利用して目 的地へ行く.

ここで，自動車利用者が道路ネットワークに関する完 全情報を持っていると仮定し, 自動車利用に対する個人 $i$ の効用関数を, (本稿で考慮する財・サービスの範囲 によって)個人 $i$ の最小一般化費用経路の旅行時間と料 金水準を説明変数として定式化する.つまり, 複数の経 路が存在する場合には，その個人にとって最も一般化費 用の小さい経路を選択するものとする，また，経路の一 般化費用は個々人の選好構造によって異なるものとし, 自動車利用の選択肢に対する効用関数における説明变数 の効用パラメータは個人ごとに異なるものとして定式化 する.

一方, 公共交通機関の効用水準に影響を与える要因 としては, 地域属性(公共交通機関へのアクセシビリテ イや利便性)，個人属性，交通機関属性(公共交通機関の 旅行時間, 料金, 快適性)などが考えられる. 本研究で は，これらの変数がロードプライシングによって変化し ないと仮定する．従って，簡単のために公共交通機関の 効用水準は個人ごとに定義される定数として定式化する.

以上のような仮定と考え方により, 式(4)のような選 択肢ごとの効用関数を定式化する.

$$
\begin{array}{ll}
U_{i}(j)=c_{i j}+\alpha_{i} t_{i j}+\beta_{i} p_{i j}, & j=\text { auto, } i \in K \\
U_{i}(j)=c_{i j}, & j=\text { transit }, i \in K
\end{array}
$$

ここで,

$c_{i j}$ : 個人 $i$, 選択肢 $j$ の効用関数の定数項

$\alpha_{i}:$ 個人 $i$ の効用関数の旅行時間パラメー夕

$\beta_{i}:$ 個人 $i$ の効用関数の料金パラメー夕

$t_{i j}, p_{i j}$ : 個人 $i$ の最小一般化費用経路の旅行時間と料金水準

式(4)における $c_{i j}, \alpha_{i}, \beta_{i}$ を地域属性, 個人属性, 卜 リップ属性の関数として定式化し, 推定した上でロード プライシングに対する潜在的な自動車利用者の対応行動 を分析すれば，個人属性や交通属性を考慮しながら，口 ードプライシングの公平性を定量的に分析することがで きると考えられる。ここで，一般性を失うことなく $c_{i, \text { auto }}$ $=0$ とすれば, 個々人を区別するパラメー夕の数は $c_{i, \text { transit }}, \alpha_{i}, \beta_{i}$ の 3 つとなる.

\section{4. 数值実験によるロードプライシングの公平性の検討}

本章では, 個々人が互いに異なる選好構造を持って いる状況を想定し, 単純な道路網上で仮想的なロードプ ライシングに対する数值実験を行い, ロードプライシン グの公平性を検討する。

\subsection{D，2 経路を対象とした数值実験}

個々人間の選好構造の異質性を考える場合, 社会的な 便益の最大化という本来の目的を達成するためのロード プライシングの形態を導くことは非常に難しい.例えば, 限界費用価格原則に基づいて料金水準を算定する既存研 究からの提案は, 同質的もしくは非弾性的な交通需要を 前提としているため ${ }^{25), 26)}$, 選好構造における個人間の 異質性と交通需要の弾力性を考慮する状況には適用でき ない．ここでは, 1OD， 2 経路の非常に単純なケースを 対象として，式(5)として定式化する，金銭として換算 された社会的な便益 $($ 金銭として換算された効用水準変 化の総和と料金収入との和）を最大にするロードプライ シング(最適料金)を公平性の観点から解釈することによ り，最初の疑問に対する知見を得ることにする.

$$
B=\sum_{i \in K} u_{i}\left(\Delta x_{i}\right) / \beta_{i}+R
$$

$R:$ 料金収入

\section{(a) 仮想状況の設定}

経路 1 と 2 が与えられているとしょう。それぞれの 経路の交通量一旅行時間関数は式(6)の BPR 関数として 定義する.

$$
\text { ここで, } t_{k}=t_{0 k}\left(1+0.15\left(q_{k} / C_{k}\right)^{4}\right) \quad k=1,2
$$$$
t_{k}: \text { 経路 } \mathrm{k} \text { の旅行時間(分) }
$$$$
t_{0 k} \text { : 交通量が } 0 \text { の時の経路 } \mathrm{k} \text { の旅行時間(分) }
$$$$
\left(t_{01}=10, t_{02}=15 \text { とする }\right)
$$$$
q_{k}: \text { 経路 } \mathrm{k} \text { の交通量(台/時) }
$$$$
C_{k}: \text { 経路 } \mathrm{k} の \text { 容量(台/時) }
$$$$
\text { ( } C_{1}=3000 \text { 台/時, } C_{2}=2000 \text { 台/時とする) }
$$

一方, 1 時間当り 8,000 人(台)の潜在的な OD 需要が存 在するとしよう. 個々人の効用関数(4)は既知で, 3 つの 効用パラメー夕は互いに独立でかつ正規分布に従ってい るとしよう(実験では, 正規乱数を発生させ, 個々人の 効用関数を特定する方法を適用した)。また，ロードプ ライシングの影響を分析する際に，個人間異質性が存在 する場合と存在しない場合との分析結果に違いが生じる かを検討するために, 表 1 のように 3 つのシナリオを設 けることにする. 
表 1 シナリオ毎の効用パラメータの分布 (平均, 分散)

\begin{tabular}{|c|c|c|c|}
\hline シナリオ & $\alpha_{I}$ & $\beta_{I}$ & $c_{\text {itransit }}$ \\
\hline 1 & $(-30,0)$ & $(-1.5,0)$ & $(-800,0)$ \\
\hline 2 & $(-30,48)$ & $(-1.5,0.12)$ & $(-800,10000)$ \\
\hline 3 & $(-30,100)$ & $(-1.5,0.25)$ & $(-800,40000)$ \\
\hline
\end{tabular}

表 2 社会的な便益を最大にする料金水準の下での公平性指標

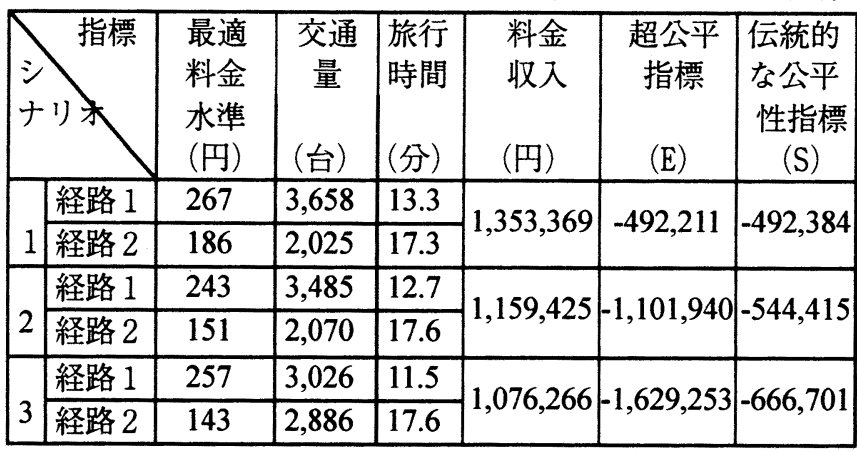

\section{(b) 数值実験の結果}

ロードプライシングの実施により，式(5)に示した金 銭尺度に基づく伝統的な社会的便益 $B$ の最大化を達成 するための，シナリ才毎の最適料金水準を探索した結果 と, 2 章で提案した 2 つの公平性指標の算出結果を表 2 に示す.なお, 料金水準毎の交通量配分状態の算出には,

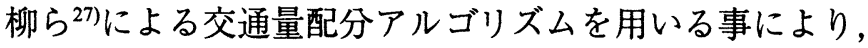
個々人の選択構造の異質性を考慮した上で利用者均衡状 態を算出している.本アルゴリズムの基本的な考え方は， 他の全ての個人の選択結果を条件として，各個人が自ら の効用関数に基づく選択を順番に行い, 全員が選択を変 更しなくなるまで繰り返す，というものである．アルゴ リズムの概要を図 1 に示す。 なお，本稿の以下の全ての 交通量配分状態の推定についても同様のアルゴリズムを 用いている。

また，本研究での数值実験において最適料金水準の 探索は, 各リンクの料金水準を外生的に与えて目的関数 が改善されるかを確認するといった方法によるものであ る.はじめに 2 つの経路における料金水準の組み合わ せからなる解空間を網羅するように多数の料金水準の組 み合わせを与えた場合の結果から空間を限定した後，そ れぞれの経路の料金水準を変更する事によって目的関数 を改善出来なくなるまで最適料金水準の探索を続けるこ ととした。

表 2 より，社会的な便益を最大にするロードプライ シングは，全てのシナリオにおいて伝統的な公平性指標 による損失を上回る料金収入を得ることが分かる。すな わち，料金収入を適切に再配分することによるロードプ ライシングの不公平性の補償可能性を示している。これ に対して，超公平指標については，シナリオ 1 と 2 では 料金収入が超公平指標の損失を上回っているものの，シ ナリオ 3 では超公平指標による損失の方が大きい. シ ナリオ 3 においては，料金収入の再配分によって新た な羡望が生まれないと仮定したとしても補償の可能性が

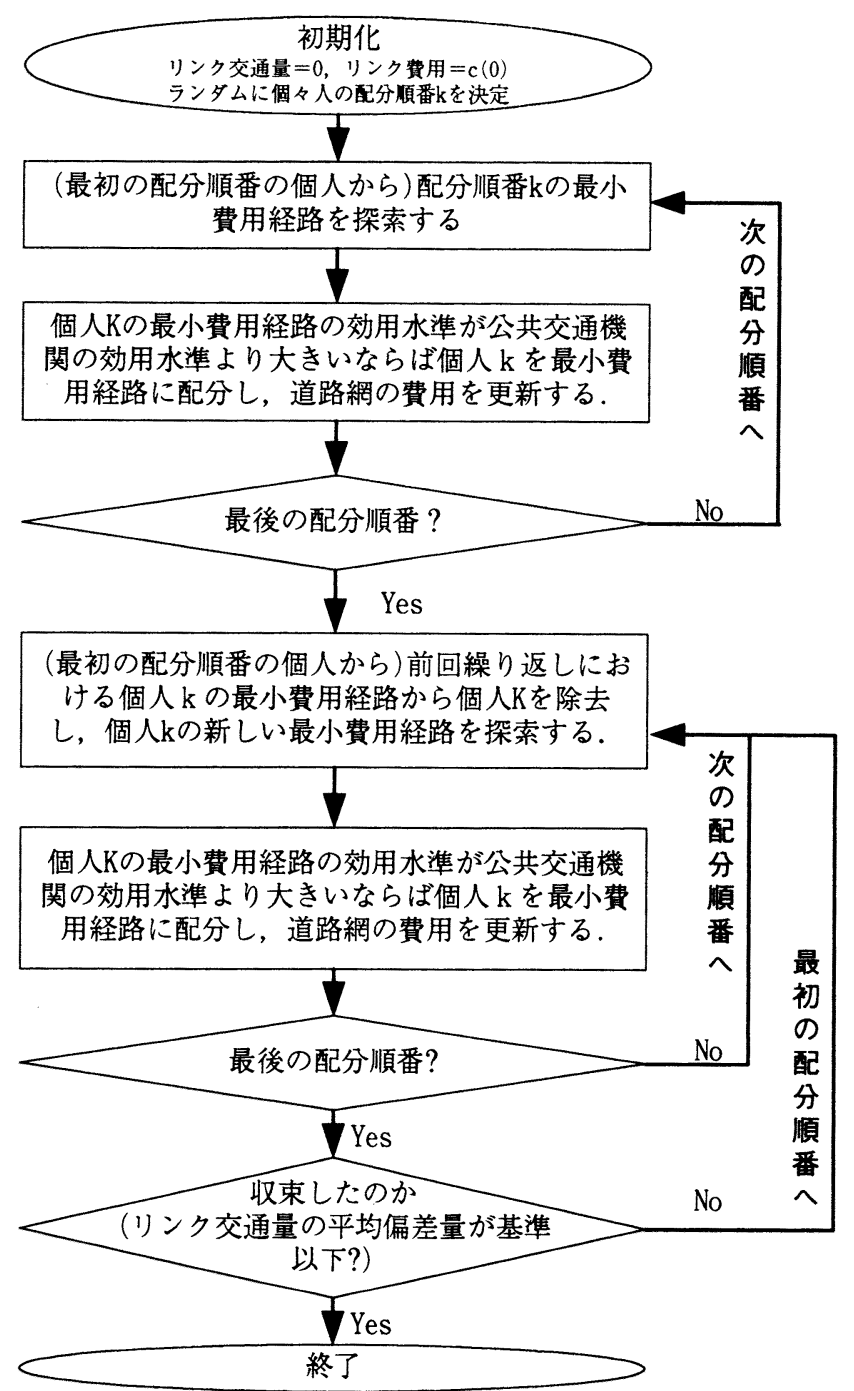

図 1 交通量配分アルゴリズム

ないことを示している.

シナリオ 2 とシナリオ 3 は共に, 全ての効用パラメ ータに個人間異質性が存在する場合であり, 異質性の分 散のみがシナリオ間で異なるため，ここでの結果より， 個人間異質性の大きさは超公平指標に影響を与える要因 であると言うことができる，すなわち，所得水準(ある いは社会階層間)の格差が大きい場合, あるいは, 公共 交通機関へのアクセシビリティの格差が大きい社会では， 人々が感じる不公平感がより大きくなる事が示されてい る.

\subsection{Many-to-Many の OD, 多経路を対象とした数值実験}

ロードプライシングに関する公平性の議論は主に， 社会経済的な属性と社会資源との配分関係を究明する問 題として行なわれているが ${ }^{15), 18) ， ロ ー ト ゙ フ ゚ ラ イ シ ン ク ゙ の ~}$ 形態によっては地域間公平性に関する分析が必要となる. 例えば，都心部へ進入する自動車に一定の料金を賦課す るというコードン賦課方式(例えば，シンガポールの ALS(Area License Scheme)やノルウェイの 3 つの都市に おけるリングロード $\left.{ }^{14}\right)$ や特定の地点，道路区間で料金 


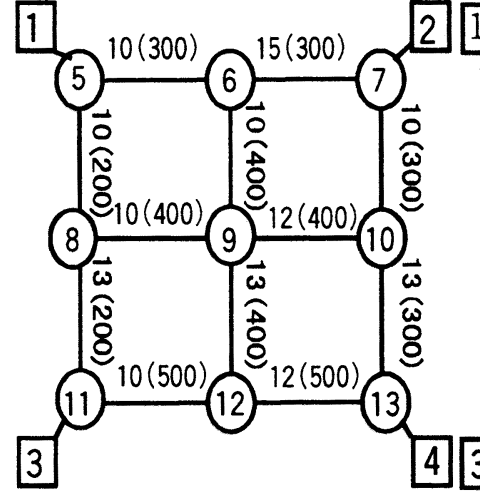

(a) $t_{0 a}\left(C_{a}\right)$

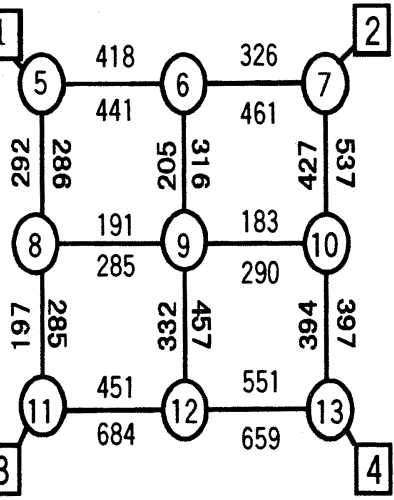

(b) リンク交通量*

*リンクの上が右方向, 下が左方向, 右が下方向, 左が上方向の交通量

図 2 ネットワークの設定 (a) と(料金なしでの) 均衡交通量 (b)

表 3 効用関数におけるパラメータの分布 (平均, 分散)

\begin{tabular}{|c|c|c|c|c|}
\hline OD & 1 & 2 & 3 & 4 \\
\hline $1 c_{i, \text { transit }}$ & & $\left(-600,120^{2}\right)$ & $\left(-600,120^{2}\right)$ & $\left(-1000,200^{2}\right)$ \\
\hline$\alpha_{i}$ & & $\left(-20,4^{2}\right)$ & $\left(-20,4^{2}\right)$ & $\left(-20,4^{2}\right)$ \\
\hline$\beta_{i}$ & & $\left(-1,0.2^{2}\right)$ & $\left(-1,0.2^{2}\right)$ & $\left(-1,0.2^{2}\right)$ \\
\hline $2 c_{i, \text { transit }}$ & $\left(-600,120^{2}\right)$ & & $\left(-1000,200^{2}\right.$ & $\left(-600,120^{2}\right)$ \\
\hline$\alpha_{i}$ & $\left(-15,3^{2}\right)$ & & $\left(-15,3^{2}\right)$ & $\left(-15,3^{2}\right)$ \\
\hline$\beta_{i}$ & $\left(-1,0.2^{2}\right)$ & & $\left(-1,0.2^{2}\right)$ & $\left(-1,0.2^{2}\right)$ \\
\hline $3 c_{i, \text { transit }}$ & $\left(-500,100^{2}\right)$ & $\left(-800,160^{2}\right)$ & & $\left(-500,100^{2}\right)$ \\
\hline$\alpha_{i}$ & $\left(-20,4^{2}\right)$ & $\left(-20,4^{2}\right)$ & & $\left(-20,4^{2}\right)$ \\
\hline$\beta_{i}$ & $\left(-1,0.2^{2}\right)$ & $\left(-1,0.2^{2}\right)$ & & $\left(-1,0.2^{2}\right)$ \\
\hline $4 c_{i, \text { transit }}$ & $\left(-800,160^{2}\right)$ & $\left(-500,100^{2}\right)$ & $\left(-500,100^{2}\right)$ & \\
\hline$\alpha_{i}$ & $\left(-15,3^{2}\right)$ & $\left(-15,3^{2}\right)$ & $\left(-15,3^{2}\right)$ & \\
\hline$\beta_{i}$ & $\left(-1,0.2^{2}\right)$ & $\left(-1,0.2^{2}\right)$ & $\left(-1,0.2^{2}\right)$ & \\
\hline
\end{tabular}

を賦課する方式では，トリップの起終点によって受ける 影響が異なってくる ${ }^{16)}$.

理想的なロードプライシングでは全ての道路区間が 料金賦課の対象となるのに対して，上述のような現実的 なロードプライシングでは，地点賦課，交通軸賦課，地 域賦課という道路網の中でも非常に限られた道路区間が 料金賦課の対象となる。

限られた道路区間を料金賦課の対象とした場合のロ ードプライシングを公平性の観点から検討するために， ここでは, Many-to-Many の OD と格子状の道路網とい う，より一般的な状況を設定し，特定のロードプライシ ングを対象として公平性を検討する。

\section{(a) 仮想状況の設定}

4 つの起終点と各々の起終点間に 1 時間あたり 1,000 人(台)の潜在需要(合計 12,000 人(台))が存在する状況を 仮定する．個々人の効用関数は，式(4)と同様に定式化 され, 3 つの未知パラメータが個人属性やトリップ属性, 地域属性などによって推定されていると仮定する。

さらに，推定された効用関数のパラメータは起終点 ごとに表 3 に示される正規分布に従っているとする．ま た，それぞれの起終点は，図 2 の(a)のような格子状の 道路網によって結ばれているとしよう(ただし，リンク
表4 政策シナリオ毎の料金賦課水準及乙賦課地点

\begin{tabular}{|c|c|c|}
\hline シナリオ番号 & 賦課リンク & (リンクごとの)料金水潐 \\
\hline 1 (地点賦課) & (12) $\rightarrow$ (11) & 200 円 \\
\hline 2 (交通軸陚武課) & (12) $\rightarrow$ (11), (13) $\rightarrow$ (12) & 100円 \\
\hline 3（地域倵課） & (12) $\rightarrow$ (11), (8) $\rightarrow$ (11) & 200円 \\
\hline
\end{tabular}

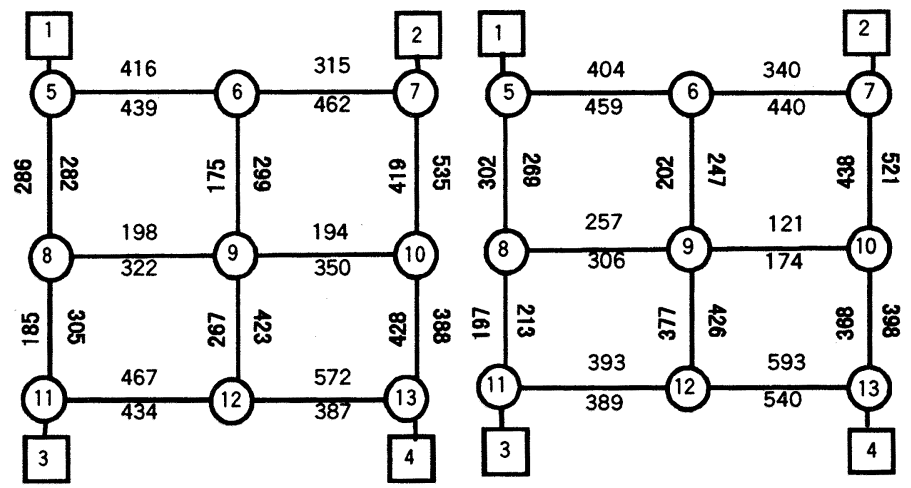

(a) シナリオ 1

(b) シナリオ 2

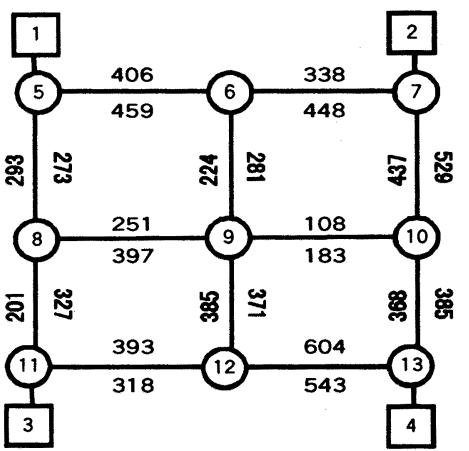

(c) シナリオ 3

図 3 政策シナリオ毎の均衡状態の推定結果

表 5 想定されたシナリオの集計的評価指標の算定結果

\begin{tabular}{|c|c|c|c|c|}
\hline シナリオ番号 & 総 $0 D$ 交通量 & 総旅行時間 & 平均旅行時間 & 平均走行速度 \\
\hline 施行前 & 3,400 & 157,072 & 46.20 & 42.338 \\
\hline 1 (地点賦課) & 3,161 & 145,642 & 46.07 & 43.034 \\
(増减率) & $(-7.03 \%)$ & $(-7.28 \%)$ & $(-0.28 \%)$ & $(+1.64 \%)$ \\
\hline 2 (軸賦課) & 3,158 & 144,949 & 45.90 & 43.409 \\
(増减率) & $(-7.12 \%)$ & $(-7.72 \%)$ & $(-0.65 \%)$ & $(+2.53 \%)$ \\
\hline 3 (地域賦課) & 3,132 & 139,317 & 43.11 & 44.229 \\
(増减率) & $(-7.88 \%)$ & $(-11.30 \%)$ & $(-6.69 \%)$ & $(+4.47 \%)$ \\
\hline
\end{tabular}

の交通量が 0 の時の旅行時間, $t_{0 a}$, と容量, $C_{a}$, はノー ド間の両方向について共通とする，また，交通量一旅行 時間関数は，式(6)の BPR 関数を用いることにする). 想 定した道路網と表 3 によって定義された潜在需要による 料金が 0 の状況での均衡状態の推定結果を図 2 の(b)に 示す.

(b)特定のロードプライシングに対する公平性の評価 ここでは，表 4 に示す 3 つの政策シナリオを設定し， それぞれの政策シナリオに対する公平性を, 2 章で提案 された 2 つ公平性指標を用いて評価し，最も公平な口 ードプライシングのあり方を探る。ここで，各シナリオ はゾーン 3 を目的地とするトリップを対象として，それ ぞれ地点賦課，交通軸賦課，地域賦課という賦課方法を 
表 6 政策シナリオの公平性評価結果

\begin{tabular}{|c|c|c|c|}
\hline シナリオ番号 & 料金収入 $R$ & 伝統的な公平性指標 $S$ & 超公平指標 $E$ \\
\hline 1 & 63,600 & $-64,303$ & $-1,793,432$ \\
\hline 2 & 81,700 & $-54,091$ & $-1,851,354$ \\
\hline 3 & 120,400 & $-77,486$ & $-1,811,263$ \\
\hline
\end{tabular}

具体化したものであるため, 賦課方法毎に賦課リンク数 や賦課リンク毎の料金水準にばらつきがあることに注意 されたい

それぞれの政策シナリオにおける均衡状態の推定結 果を図 3 に示す。また，各々のシナリオが交通システム に与える影響を, OD 需要の変化と共に, 伝統的な交通 政策の成果指標としてよく使われている旅行時間及び走 行速度を用いてまとめた結果を表 5 に示す。

表 5 より, 提案された 3 つの政策シナリオによる交 通需要の削減効果に大きな差は見られないが, 政策シナ リオ 1,2 は平均旅行時間や平均走行速度といった渋滞 緩和効果は小さいことが分かる。これに対して，政策シ ナリオ 3 は，渋滞緩和という面から非常に大きな効果を もたらすものとして評価される.

また，想定された 3 つの政策シナリオを，2 つの公平 性指標を用いて評価した結果を表 6 に示す，表 6 より, 伝統的な公平性指標では政策シナリオ 3(地域賦課)が, 超公平指標では政策シナリオ 2 (交通軸賦課)がより不公 平な政策として評価されることが分かる．また，料金収 入を再配分してロードプライシングの不公平性を修正す ると考えれば，伝統的な公平性指標では政策シナリオ 3 が最も公平性を修正できると考えることができる．しか し, 超公平指標に関しては常に超公平指標による損失が 料金収入を大幅に上回る結果となった. 全ての道路区間 を対象としてロードプライシングを導入した場合の結果 である表 2 では超公平指標による損失が料金収入を下回 るシナリオが存在した事も考え合わせると，限られた道 路空間に対してロードプライシングを実施した場合には, その影響が ODによって大きく異なるため不公平感がよ り大きくなる事を示しているものと考えられる.

\section{5. 料金収入の配分と公平性}

ロードプライシングを公平性の観点から検討した多 くの研究がロードプライシングの不公平性の修正方法と して料金収入の再配分を提案しており 5),8,17)，料金収入 の実質的な配分方法を提案した研究も幾つか行なわれて いる99,21),28). 具体的な方法としては一般税金の減税, 道 路建設，公共交通サービス改善21)や，これらに地域の環 境改善, 通行者に対する支援(通勤手当て)を加えた方法9) が提案されている.

本研究ではこれらの提案の中で, 幾つかの料金収入 の再配分方法を, 単純な仮定の下で再構成し, それぞれ の再配分方法がロードプライシングの不公平性をどの程
表 7 Many-to-Many の OD における不公平感の予測モデル

\begin{tabular}{|c|c|c|}
\hline 説明変数名 従属変数 & $\begin{array}{l}\text { 伝統的な } \\
\text { 公平性指標 }\end{array}$ & 超公平指標 \\
\hline \multicolumn{3}{|l|}{ 起終点ダミー変数 } \\
\hline ゾーン 3 を起点とする & 31.00 & 188.08 \\
\hline ゾーン 3 を終点とする & 98.19 & 188.74 \\
\hline \multicolumn{3}{|l|}{ 交通機関ダミー変数 } \\
\hline R.P の施行前に自動車利用 & -7.31 & $7.82^{* *}$ \\
\hline P.R の施行後に自動車利用 & 32.92 & 24.70 \\
\hline \multicolumn{3}{|l|}{ 効用関数のパラメータ } \\
\hline 定数項 $\left(c_{i, \text { transit }}\right)$ & $-0.004^{*}$ & -0.33 \\
\hline 料金パラメータ $\left(-\beta_{1}\right)$ & 39.38 & 35.79 \\
\hline 旅行時間パラメータ $\left(-\alpha_{\mathrm{I}}\right)$ & -1.95 & 16.05 \\
\hline 定数項 & -54.18 & -142.66 \\
\hline R square & 0.76 & 0.55 \\
\hline 標本数 & 3559 & 3559 \\
\hline F值 $\quad$ 自由度 $=(7,3551)$ & 1663.07 & 609.42 \\
\hline (モデルの有意水準) & $(0.00)$ & $(0.00)$ \\
\hline
\end{tabular}

* 有意水準 $1 \%$ で帰無仮説 (回帰係数=0) が棄却できない.

** 有意水準 $5 \%$ で带無仮説 (回㷌係数=0) が棄却できない.

度修正できるかを検討する.さらに前章までの分析では， 料金収入の再配分によって均衡状態が変化しないものと 仮定していたが，ここでは料金収入の再配分に伴い個々 人が選択を変更することを考慮し, 新たな均衡状態での 両指標による公平性評価を行う. 分析対象として, 4.2 における料金賦課シナリオ 3(地域賦課)を取り上げ，再 配分による影響を測定する。

\section{1 料金収入の再配分対象の選定}

本研究では，ロードプライシングによって，より大 きい悪影響を受けるセグメントに対して料金収入を優先 的に再配分することを考える.ここでは, 料金収入の再 配分対象を抽出する目的で, 以下の不公平感を従属変数 とする回帰モデルを用いている.

$$
y_{i}=\sum_{m} \theta_{k} x_{i m}+\varepsilon_{i}
$$

ここで,

$y_{i}:$ ロードプライシングによる個人 $i$ の不公平感

$x_{i m}:$ 個人 $i$ の $m$ 番目の属性

$\theta_{m}: m$ 番目の個人属性に対する回帰係数

$\varepsilon_{i}:$ 誤差項

回帰モデル(式(7))における従属变数としては, 伝統的 な公平性指標と超公平指標の双方が考えられるため, 両 指標を従属变数とした $2 つ$ 回帰モデルを推定した. ま た, 説明変数としては, 効用関数(式(4))における個々人 の効用パラメータやトリップの起終点を表す变数を検討 している.なお, ここでは分析を単純化するために, 起 点がゾーン 3 であるトリップと終点がゾーン 3 であるト リップを示すダミー変数を導入し, 他の起終点を持つト リップへの影響と比較することにする．また，ロードプ ライシングの施行前後に利用する交通機関を示す変数と して2つのダミー変数を加える. 以上のように回帰モデ ルを定式化した上で，モデルのパラメータを推定した結 果を表 7 に示す. 
表 8 料金収入の再配分方法とパラメータ設定方法

\begin{tabular}{|c|c|c|c|}
\hline $\begin{array}{l}\text { シナ } \\
\text { リオ } \\
\text { 番号 }\end{array}$ & $\begin{array}{c}\text { 再配分 } \\
\text { 方法 }\end{array}$ & パラメータ設定方法 & $\begin{array}{l}\text { 料金収入の } \\
\text { 配分政策案 }\end{array}$ \\
\hline 0 & \multicolumn{3}{|c|}{ 料金収入を配分しない } \\
\hline 1 & $\begin{array}{l}\text { 通勤 } \\
\text { 手当 }\end{array}$ & $\begin{array}{l}\text { 最小一般化費用経路の } \\
\text { 料金水準を下げる効 } \\
\text { 果, すなわち, } \\
p_{i j a}=p_{i j}-m_{1}\end{array}$ & $\begin{array}{l}\text { ゾーン } 3 \text { を目的ゾ } \\
\text { ーンとする全トリ } \\
\text { ツプに料金収入を } \\
\text { 均等に金錢として } \\
\text { 配分する. }\end{array}$ \\
\hline 2 & $\begin{array}{l}\text { 公共 } \\
\text { 交通 } \\
\text { 支援 }\end{array}$ & $\begin{array}{l}\text { 最小一般化費用経路の } \\
\text { 効用水準低下 } \rightarrow \text { 公共交 } \\
\text { 通サービス水準の向 } \\
\text { 上, すなわち, } \\
c_{i 1 a}=c_{i 1}-m_{2}{ }^{*} \beta_{i}\end{array}$ & $\begin{array}{l}\text { ゾーン } 3 \text { を起点, } \\
\text { または終点とする } \\
\text { 公共交通機関の利 } \\
\text { 便性を向上する. }\end{array}$ \\
\hline 3 & $\begin{array}{l}\text { 道路 } \\
\text { 建設 }\end{array}$ & （経路選択への影響） & $\begin{array}{l}\text { ノード } 9 \text { と } 11 \text { を両 } \\
\text { 方向で結ぶ道路区 } \\
\text { 間を建設する. }\end{array}$ \\
\hline 4 & $\begin{array}{l}\text { トール } \\
\text { 道路の } \\
\text { 建設 }\end{array}$ & （経路選択への影響） & 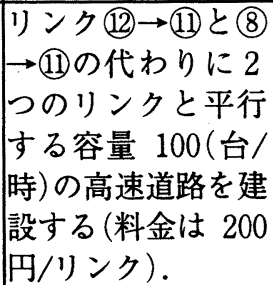 \\
\hline
\end{tabular}

注） $p_{i j a}$ : 料金収入の再配分後の個人 $\mathrm{i}$ の最小費用経路経路 $\mathrm{j} に$ 対する料金水準の知覚値,

$m_{1}=R / N_{1}$ : ゾーン 3 を目的ゾーンとするトリップ $\left(N_{1}\right)$ に与 えられる通勤手当額,

$m_{2}=R / N_{2}$ : ゾーン 3 を目的ゾーン, または, 出発ゾーンと する公共交通機関利用者 $\left(N_{2}\right)$ への平均支援額,

$c_{i 1 a}$ : 公共交通サービス水準が向上された場合の個人 i の最 小費用経路に対する定数的な効用水準.

伝統的な公平性指標と超公平指標によるそれぞれの 回帰モデルから共通点を取り出すと, 次のような属性を 持つセグメントを料金収入の再配分対象として抽出する ことができる：ゾーン 3 をトリップの起点もしくは終点 とし，ロードプライシングの施行後にも自動車を利用し て通行する低所得層, または，公共交通サービスレベル が低い階層.

\section{2 料金収入の再配分シナリオ}

前節での分析結果に基づき，不公平性を修正するた めの料金収入の再配分方法と各再配分方法におけるパラ メータの設定方法を表 8 に示すように設定した。ここで, 料金収入を道路建設に使うシナリオ 3 では，建設される 道路区間を具体化(容量, 交通量一旅行時間関数, 接続 される交差点等)する必要がある。ここでは,ゾーン 3 を起点, または終点とする自動車利用者が共に利用する 可能性が高いノード 9 と 11 を両方向で結ぶ道路区間を 想定する。 そして, リンクの容量は連続的に拡張可能な ものとし，料金収入によって決まるものとする，具体的 には次の仮定を設けておく.
表 9 料金収入の再配分シナリオ毎の公平性評価結果

\begin{tabular}{|c|r|r|r|r|}
\hline シナリオ & $\begin{array}{c}\text { 自動車 } \\
\text { 利用者 }\end{array}$ & $\begin{array}{c}\text { 伝統的な } \\
\text { 公平性指標 }\end{array}$ & 超公平指標 & $\begin{array}{c}\text { 総旅行時間の } \\
\text { 変化(分) }\end{array}$ \\
\hline 0 & 3,130 & $-77,486$ & $-1,811,263$ & $-17,755$ \\
\hline 1 & 3,204 & $-51,245$ & $-1,860,478$ & $-13,940$ \\
\hline 2 & 3,052 & $-60,904$ & $-1,809,653$ & $-21,215$ \\
\hline 3 & 3,228 & $-57,579$ & $-1,770,487$ & $-8,696$ \\
\hline 4 & 3,429 & $-3,211$ & $-1,482,421$ & +624 \\
\hline
\end{tabular}

$$
C_{9 \rightarrow 11}=C_{11 \rightarrow 9}=R / 400
$$

ここで, $\quad c_{i \rightarrow j}$ : 交差点 $\mathrm{i}$ から $\mathrm{j}$ を結ぶリンクの容量

式(8)は，道路区間は両方向とも同じ容量を持つよ うに建設すること，及び，容量を 1 台分増加するため に 200 円の費用がかかることを意味する．また，この リンクの交通量が 0 の時の旅行時間は 10 分と設定す る.

表 8 における料金収入の再配分シナリオ 3 が建設 される道路の容量が料金収入によって決定される内生 変数であるのに対して，シナリオ 4 は，料金収入によ る制限を設けないケースを表すものである。シナリオ 4 は, 従来から存在するリンク(この場合は(12) $\rightarrow(11)$ と (8) $\rightarrow$ (11)）に料金を賦課するのではなく, 従来のリンク に平行に新たにトール道路を建設するというものであ り, 他のシナリオとは根本的に異なる. Poole ${ }^{299}$ は, シナリオ 4 のように新しいトール道路を建設すること に対する自動車利用者の反対がないことから，このよ うなロードプライシングの導入形態が公平性の観点か ら望ましいと主張している。よって，シナリオ 4 はロ ードプライシングによる料金収入の再配分方法という 本研究での分析対象範囲には含まれないものの, この ようなシナリオの公平性を定量的に確認するために，他 のシナリオと合わせて分析する事とする.

\section{3 料金収入の再配分方法と公平性}

表 8 に示した料金収入の再配分シナリオは個々人の 交通行動に変化を与えるものと考えられるため, 料金収 入の再配分を考慮した場合の均衡状態を改めて推定する 必要がある.ここでは, 前述の柳らの交通量配分アルゴ リズムに基づく繰り返し計算により均衡状態を算出した。 結果から得られた集計的な評価值を表 9 に示す。なお, 表 9 において総旅行時間の変化は自動車利用者の增減に よる影響も含まれたものであることに注意されたい。

表 9 より，シナリオ 4 が両指標から最もロードプラ イシングの不公平性を修正できることが分かる。この結 果は Poole の主張と整合すると考えることができる．し かしながら，シナリオ 4 は料金収入による制限を設けて いないケースであり，料金収入による制限を受けるその 他のシナリオの中では，公共交通機関を支援するシナリ オ 2 や料金収入の範囲で代替経路を提供するシナリオ 3 はいずれの公平性指標(不公平感)をも緩和することがで 
きるものと考えられる．通勤手当を支給するシナリオ 1 は伝統的な公平性の面からは望ましいと評価することが できるが, 超公平理論からは不公平性をより悪化させる ものとして評価されている.

\section{6. まとめ}

本研究では，ロードプライシングの公平性を定量的 に分析することを目的とし，定量的な評価指標として 2 つの指標(伝統的な公平性指標と超公平指標)を提案した。 伝統的な公平性指標は，これまでの研究で用いられてい る公平性の概念(例えば， Else $^{6}$, Small ${ }^{9}$, Goodwin ${ }^{21)}$ 等) を表し, 超公平指標は, (完全情報の下で)人々が他者と の比較によって感じる公平性を表すものとして考えるこ とができる。

仮想状況を対象とした数值実験を行い，ロードプラ イシングの公平性を，提案された $2 つ の$ 公平性評価指標 を用いて分析した結果, 公平性の観点からはロードプラ イシングを広域的に施行することが望ましいという知見 を得た。しかし，このような知見は料金収入の適切な再 配分を前提とするため，現実的な料金収入の再配分方法 と公平性の関係についても検討を行った。 その結果，公 平性の観点から最も望ましい料金収入の再配分方法は, ロードプライシングの基本的な目的を損なわない範囲で 道路建設の財源に充てることであると示された.

Giuliano ${ }^{8)}$ が言及したように, 公平性議論がロードプ ライシングという有効な政策の障害になってはならない が, 政策の施行において可能な限りの市民の不公平感を 改善する工夫が必要と思われる. ここで, 本研究で提案 された超公平指標が役立つものと考えられる。

本研究では潜在的な自動車利用者のみを分析対象と したが非自動車利用者に関しても分析を広げる必要があ ると考えられる。また，現実のネットワークを对象とし て分析を行うためには，人々の行動をより詳細に分析す る必要があり, 今後の課題としたい。

\section{参考文献}

1) 小林清晃 : 交通混雑制御への待ち行列モデルによるアプロ 一千, 経済論丵(京都大学) 第 155 巻第 1 号, pp. 22-35, 1995.

2) Arnott, R., Palma, A. De and Lindsey, R. : Schedule Delay and Departure Time Decision with Heterogeneous Commuters, Transportation Research Record 1197, pp. 56-67, 1988.

3) Hendrickson, C. and Kocur, G. : Schedule Delay and Departure Time Decisions in a Deterministic Model, Transportation Science 16, pp. 62-87, 1982.

4) Carey, M. : Network Equilibrium ; Optimization Formulations with Both Quantities and Price as Variables, Transportation Research 21B, No.1, pp. 69-77, 1987.
5) Morrison, S. A. : A Survey of Road Pricing, Transportation Research 20A, No.2, pp87-97, 1986.

6) Else, P. K. : No Entry for Congestion Taxes?, Transportation Research 20A, No.2, pp. 99-107, 1986.

7) May, A. D. : Road Pricing ; An International Perspective, Transportation 19, pp. 313-333, 1992.

8) Giuliano, G. : An Assessment of the Political Acceptability of Congestion Pricing, Transportation 19, pp. 335-358, 1992.

9) Small, K. A. : Using the Revenues from Congestion Pricing, Transportation 19, pp. 359-381, 1992.

10) Lave, C. : Demand Curve under Road Pricing and the Problem of Political Feasibility, Transportation Research 28A, No. 2, pp. 8391, 1994.

11) Richards, M., Gillian, C. and Larkinson, J. : U.S Experience with Congestion Pricing, ITE Journal 63, No.12, pp. 66-71, 1993

12) Hau, T. D. : Urban Transport Demand Management in Hong Kong : 1973-1994, Presented at the Expert Hearing on Road Pricing System at the University of Stuttgart, Germany, 1995.

13) Higgins, T. J. : Road Pricing Attempts in the States(1986), Transportation Research 20A, No. 2, pp. 145-150, 1986.

14) May, A. D. : International Experiences with Congestion Pricing, ITE Journal 63, No. 12, pp. 14-20, 1993.

15) Decorla-Souza, P. : Congestion Pricing; Issues and Opportunities, ITE Journal 63, No. 12, pp. 27-32, 1993.

16) Wilson, P. W. : Welfare Effects of Congestion Pricing in Singapore, Transportation 15, pp. 191-210, 1988.

17) 山内弘隆, 竹内健蔵: 混雑税理論の展望一経済学の視点, 土木学会論文集 No.449/IV-17, pp. 17-26, 1992.

18) Starkie, D.:Efficient And Politic Congestion Toll, Transportation Research 20A, No. 2, pp. 169-173, 1986.

19) Decorla-Souza, P. and Kane, A. R.:Peak Period Pricing; Precepts and Prospects, Transportation 19, pp. 293-311, 1992.

20) Bhatt, K.:Implementing Congestion Pricing ; Winner and Losers, ITE Journal 63, No, 12, pp. 33-37, 1993.

21) Goodwin, P. B. : The 'Rule of Three'; A possible solution to the political problem of competing objectives for road pricing, Traffic Engineering and Control 30, pp. 495-497, 1989.

22) 太田和博 : 集計の経済学, 文傎堂, 1995.

23) Baumol, W. J. : Superfairness-Theory and Application, The MIT Press, 1987.

24) National Research Council : Curbing Gridlock : Peak-period Fee To Relieve Traffic Congestion, Vol. 1, National Academy Press, 1994.

25) Leurent, F. : Cost Versus Time Equilibrium over a Network, Transportation Research Record, 1443, pp. 84-91, 1994.

26) Dial, R. B : Network Optimized Congestion Pricing ; A Parable, Model And Algorithm, U.S Environmental Protection Agency, 1995.

27) 柳 時均, 山本 俊行, 北村 隆一: ロードプライシングの 評価における公平性基準の適用可能性に関する一考察, 第 18 回交通工学研究発表会論文報告集, pp. 169-172, 1998.

28) Jones, P. : Gaining Public Support for road pricing through a package approach, Transportation Engineering and Control 32, pp. 194-196, 1991.

29) Poole, R. W. Jr. : Introducing Congestion Pricing on a New Toll Road, Transportation 19, pp. 383-396, 1992. 
本研究では，ロードプライシングの公平性を評価するために，個人の効用の変化に着目した(伝統的な)公平性指標と， 他人との比較によって生じる不公平感を表す超公平指標を導入した．さらに，選好構造の個人間異質性を考慮した仮想 状況を設定し，特定のロードプライシングによる影響を推定すると共に，提案された評価指標を用いて公平性の面から ロードプライシングを解釈する数值実験を行った。また，料金収入がロードプライシングの不公平性をどれくらい修正 できるかを検討するために，現実的にありうる料金収入の再配分方法を想定し，その結果を解釈した。 これらの一連の 分析から，ロードプライシングの不公平性を修正する最も有効的な方法として料金収入を道路建設の財源にする方法と 通勤手当として支給する方法が結果として得られた。

A Study on the Fairness of Road-Pricing

Sikyun Ryoo, Toshiyuki Yamamoto, Ryuichi Kitamura

This study explores the characteristics of road-pricing with respect to its fairness. We introduce two types of fairness criteria and examine the characteristics of them based on the results of numerical experiments, taking into account the heterogeneity in preference. The results suggest the following : Road-pricing is certainly a regressive and unfair program with respect to both the traditional fairness concept and the superfairness concept. As the best way of using the revenue from congestion pricing, two types of compensating programs, construction of a new toll road and funding employee commuting allowances, are suggested. 